556 MARY ENGLE PENNINGTON AND GEORGE C. KÜSEL.

of Texas, California, and Canadian petroleums, with high boiling-points, is now in progress.

A summary of the results obtained in the examination of this petroleum is given in the following table:

\begin{tabular}{|c|c|c|c|c|c|}
\hline \multirow[b]{2}{*}{$\mathrm{C}_{14} \mathrm{H}_{26}$} & \multirow[b]{2}{*}{$\begin{array}{l}\text { R. P. }(25 \mathrm{~mm} .) \\
125^{\circ}-130^{\circ}\end{array}$} & \multirow[b]{2}{*}{$\begin{array}{l}\text { Sp.gr. } \\
0.87 \text { II }\end{array}$} & \multirow{2}{*}{$\begin{array}{l}\text { Index of } \\
\text { refraction. }\end{array}$} & \multicolumn{2}{|c|}{ Molecular refraction } \\
\hline & & & & $\begin{array}{c}\text { Calculated. } \\
62.34\end{array}$ & $\begin{array}{r}\text { Found. } \\
62.39\end{array}$ \\
\hline $\mathrm{C}_{15} \mathrm{H}_{28}$ & $140^{\circ}-145^{\circ}$ & 0.8788 & I. 4746 & 66.94 & $66.7^{\circ}$ \\
\hline $\mathrm{C}_{16} \mathrm{H}_{30}$ & $160^{\circ}-165^{\circ}$ & 0.8894 & 1.4672 & & 69.40 \\
\hline $\mathrm{C}_{17} \mathrm{H}_{34}$ & $\mathrm{I} 75^{\circ}-180^{\circ}$ & 0.8966 & $\mathrm{I} .472 \mathrm{I}$ & 76 & 73.85 \\
\hline $\mathrm{C}_{19} \mathrm{H}_{36}$ & $195^{\circ}-200^{\circ}$ & 0.9020 & I. 4928 & 85.35 & 84.70 \\
\hline $\mathrm{C}_{21} \mathrm{H}_{38}$ & $215^{\circ}-220^{\circ}$ & 0.9163 & I. 4979 & 92.46 & $92.9 \mathrm{I}$ \\
\hline $\mathrm{C}_{25} \mathrm{H}_{45}$ & $270^{\circ}-275^{\circ}$ & 0.9410 & 1.5152 & 110.87 & III.OO \\
\hline
\end{tabular}

[CONTRIBUTION FROM THE LABORATORY OF HYGIENE, UNIVERSITY OF PENNSYLVANIA.]

\title{
AN EXPERIMENTAL STUDY OF THE GAS-PRODUCING POWER OF BACILLUS COLI COMMUNIS UNDER DIFFERENT CONDITIONS OF ENVIRONMENT.
}

By Mary ENGLE PENNATGTON AND GEORGE C. KÜSEL. Recelved fine 29 . 1900 .

THE power which some bacteria possess of liberating certain gaseous elements and compounds from suitable culture media has been the subject of a number of investigations. These investigations have brought to light many interesting facts, and have established methods of diagnostic value based upon gas production. Dr. Theobald Smith, in the account of his now classic experiments upon fermentation, has given a number of species which produce gases, the necessary conditions, quantity of gas produced, etc. Various analyses are on record, also, of the gas liberated, these analyses being more or less detailed depending upon the point of view of the investigator and the time when the work was done. Among the earlier workers we find, generally, that they were content with the determination of the amount of carbon dioxide. The residual gas, being found to be explosive, was accepted as hydrogen.

Later studies have been made with more care, and in consequence the presence of other gases has been recognized. Pammel and Bennett ${ }^{1}$ have studied the action of several gas-producing organisms with especial attention to their behavior toward

1 This Jourtal, 18, 157 (1896). 
different sugars; namely, glucose, cane-sugar, and lactose. They mention the fact that the first portions of escaping gas are nearly pure hydrogen, but are inclined to ascribe this to the absorptive power for carbon dioxide possessed by the medium. The culture period for each experiment is given, and the analytical data, obtained by growing the organisms in various media, are couspared, but nothing further regarding the progressive alteration in the composition of the gas formed is noted.

Some fermentation work with Bacillus coli communis which has been done in this laboratory, led us to believe that a change in the composition of the gas does occur with the advancing age of the culture and, also, that appreciable quantities of gases other than hydrogen and carbon dioxide are formed. The work in this laboratory also indicated that gas production by Bacillus coli communis in glucose bouillon in the usual saccharimeter tube is not so constant, either in relation to time of gas production or of the amount produced, as is generally believed. It seemed advisable, therefore, to cultivate this organism under the most concordant conditions possible, and to submit the gases produced to a careful chemical examination.

The chemist who undertakes quantitative chemico-bacteriological work has found in the past, and still finds, a source of error which at present seems insurmountable. This error lies in the quantity and quality of the inoculating material. Wherever inoculations are to be made the most careful work of trained eyes and skilled hands may yet leave a margin, plus or minus, of untold thousands of organisms, for with cells so prolific as are bacteria a small difference to-day is enormous to-morrow. Not only, too, must we consider the number of active organisms produced, but the waste products of those cells which are already dead may exert an appreciable influence upon later comers.

The gas-producing ability certainly varies considerably with the age of the culture. Many trials have demonstrated that Bacillus coli communis made upon nutrient agar are most active, so far as gas production is concerned, when three days old, the organisms having been kept at a temperature of $37^{\circ} \mathrm{C}$. Older cultures, as a rule, produce less gas. This may be due to a decreased vitality of the germ from lack of food supply or from noxious waste products. In all of the experimental work given 
below a three days' slant culture on agar was used as the seed. ing material.

After many trials with the various forms of apparatus for the collection and isolation of the gases generated by bacteria the following method was devised and used exclusively. The advantage of this form of apparatus is that it is easily handled, cleaned, and sterilized, besides being perfectly tight. That it is

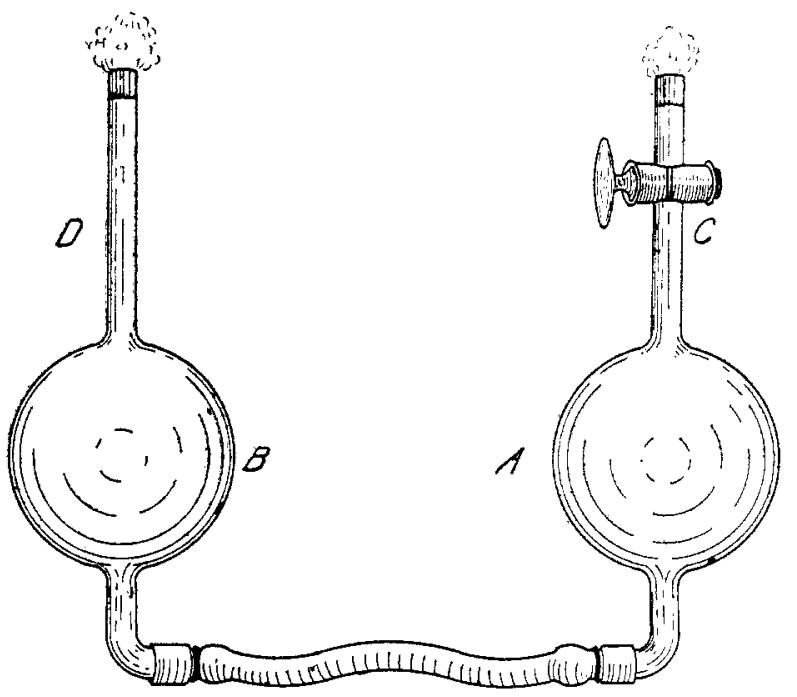

exceedingly simple will be seen from the accompanying diagram. $A$ is a glass bulb of $250 \mathrm{cc}$. capacity having an inlet, $C$, three inches long, into which a glass stop-cock is fused and an outlet $D$, of the same length, bent at right angles about one inch below the bulb. $B$ is a like bulb except that the stop-cock is omitted. Heavy walled rubber tubing connects these two bulbs and is closely wired, both outlets being roughened to facilitate this. The inlets are plugged with cotton-wool, when the apparatus may be sterilized in an autoclave.

In the experiments to be described exactly $250 \mathrm{cc}$. of the desired culture medium were admitted through $D$ the stop-cock of $C$ being open. The level was then adjusted until the bore of the stop-cock was just filled. The cock was turned, and the apparatus, so far as $A$ was concerned, was tight. Resterilization 
in an autoclave at 45 pounds' pressure rendered the apparatus fit for inoculation. This was performed either by slipping a platinum wire through the stop-cock bore until it met the medium, or, as we preferred, by placing a definite number of drops of a suspension culture in the inlet tube $C$ and drawing them into the bulb by lowering $B$.

As the organisms multiply, the gas collects in $A$ displacing the liquid and forcing it over into $B$. The flexible connection between the two bulbs enables one to readily adjust the levels so that undue pressure, which checks fermentation, is obviated. The bulbs have been allowed to stand for days with bulb $B$ depressed to its fullest extent but not the slightest inward leakage has been detected. When the experiments were being conducted a slight pressure in $A$ was maintained as an additional precaution, so that the leak, if any, should be outward.

All the experiments were conducted at an incubator temperature, $37^{\circ} \mathrm{C}$. The media were made with the greatest exactness possible. Commercial peptone, glucose, and salt were carefully dried and weighed accurately. When bouillon was desired Liebig's "Extractum Carnis" was used. The reaction of the medium was always neutral at the beginning of the experiment. Tenth-normal sodium hydroxide was used for this neutralization, phenolphthalein being the indicator. The gases were withdrawn from the bulb after cooling the latter to $18^{\circ}$ to $19^{\circ} \mathrm{C}$. and analyzed over mercury in a Hempel apparatus. Hydrogen was determined by explosion with oxygen. Hydrocarbons were determined by residual carbon dioxide. Nitrogen was found by difference. Heavy hydrocarbons were sought, but were not detected. All results are expressed in percentages. The amount of gas produced did not, as a rule, permit of more than one accurate carbon dioxide analysis. After absorbing the carbon dioxide, however, duplicate determinations of hydrogen, nitrogen, and methane were made. To exclude the personal error all the analyses were made by one person. When the variation in the results were large the experiments were submitted to a bacteriological investigation, but the cultures were found to be pure.

NITROGEN AND METHANE.

A series of bulbs were filled as above described with neutral 
bouillon containing I per cent. peptone, 0.5 per cent. sodium chloride, 0.5 per cent. Liebig's beef extract, and 1.5 per cent. glucose. The individual bulbs were analyzed at the expiration of the periods indicated in the table.

TABLE I.

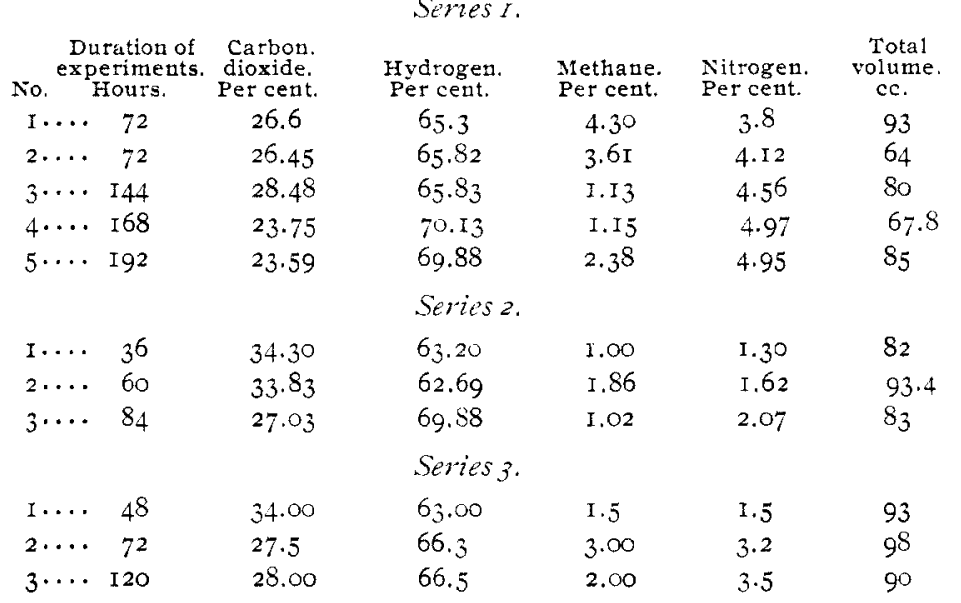

According to Table $I$, in addition to the carbon dioxide and hydrogen, the gases usually present, we find also nitrogen and methane. These gases were invariably found, and their presence in such appreciable quantities is of interest. Grimbert ${ }^{1}$ has cultivatęd Bacillus coli communis in the presence of amido bodies, nitrates and nitrites, and states that amides are necessary if denitrification processes are to continue. In Grimbert's experiments sugar was not mentioned, the study being made in nitrated, or amidated, peptone solutions exclusively. In Bennett and Pammel's work we find no mention of nitrogen or methane in the gas produced. Wolff, ${ }^{1}$ in a recent paper on denitrification, states that this organism reduces a nitrated peptone-glucose medium, giving nitrites.

Frequent repetition of our experiments, where no nitrates were added, with every possible precaution against admixture of air, gave invariably some nitrogen. The question therefore arose: Does the presence of air in bulb $B$ affect the nitrogen production?

inn.d. 'Inst., Pasteur, 13, 67 (1889).

2 Hygien. Rundsch., 9, I 69. 
While fermentation is active the tendency would be to carry the organisms out of the field of activity (bulb $A$ ) and a backward migration cannot be very extensive. But at the close of the active period the organisms in $B$, may find their way into $A$ again. Do they, from their contact with the oxygen at the surface of the liquid in $B$, become so modified physiologically that they alter the usual course of fermentation? To determine this point the following experiments were made in which all oxygen was excluded.

The apparatus above described was filled and sterilized in the usual manner. A Geissler potash bulb containing a freshly prepared pyrogallol and sodium hydroxide solution was attached to $B$, and a wash-bottle rigged flask, containing a like solution, was attached to $A$; the stop-cock was then opened, the level of $A$ raised and the liquid allowed to flow into $B$, until the bulb was quite full. The air entering $A$ was, of course, deprived of oxygen by the pyrogallate in the wash-bottle flask. The relative levels were next altered and bulb $A$ refilled. The air in $B$ was free from oxygen and remained so as indicated by testing over active phosphorus. The gas produced under such conditions still showed nitrogen, but we were surprised to find that hydrocarbons had disappeared (see Table II).

TABLE II.

Series $I$.

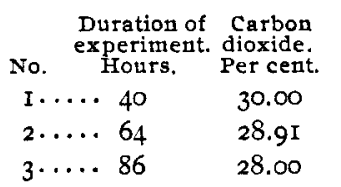

I.....22

$2 \ldots 3^{6}$

$3 . \cdots 64$

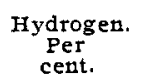

67.80

67.53

66.99

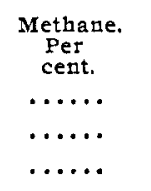

Series 2.

......

1.72

83

60.10

…. 3.10

…. 4.82

97

59.18

94

Series I and 2 of Table II were made with glucose bouillon of the composition given, and, except that the series were started on different days, were as exactly alike as possible. The results show well the marked variation which frequently appears, and which will be again met with in the course of this paper. 
Control bulbs without the pyrogallate tubes were made in each case, and the analyses always showed hydrocarbons to be present. Hence we find that the entire exclusion of oxygen does not modify the nitrogen production in the least but that under such circumstances hydrocarbons are not produced.

In the foregoing experiments the organisms had a large supply of amido nitrogen on hand in the form of meat extractives. They had, also, the proteid nitrogen of the peptone. Commercial peptone varies considerably in composition and contains always more or less amido nitrogen. If the organisms are able to reduce the nitrogen of the extractives only we would expect to find much less nitrogen in a peptone-glucose solution than in one containing meat extractives in addition to the other constituents.

To determine to what extent these added meat extractives enter into the nitrogen evolved, the following series of bulbs were made with a culture medium composed of I per cent. peptone (Witte's) containing 1.5 per cent. glucose and 0.5 per cent. salt. The pyrogallate bulbs were not attached.

TABLE III.

Series 1 .

\begin{tabular}{|c|c|c|c|c|c|}
\hline 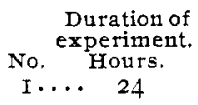 & $\begin{array}{c}\text { Carbon. } \\
\text { dioxide. } \\
\text { Pet cent. } \\
34.80\end{array}$ & $\begin{array}{l}\text { Hydrogen. } \\
\text { Per } \\
\text { cent. } \\
65 . \text { II }\end{array}$ & $\begin{array}{c}\text { Methane. } \\
\text { Per } \\
\text { cent. } \\
\ldots . .\end{array}$ & $\begin{array}{l}\text { Nitrogen. } \\
\text { Per } \\
\text { cent. } \\
0.09\end{array}$ & $\begin{array}{c}\text { Tota1 } \\
\text { volume. } \\
\text { cc. } \\
\text { IOO.O }\end{array}$ \\
\hline $2 \ldots \quad 48$ & 30.2 & 62.83 & I. 63 & 5.34 & 97.4 \\
\hline $3 \cdots 120$ & 28 . I I & 64.6 & 1.80 & 5.49 & 86.0 \\
\hline \multicolumn{6}{|c|}{ Series 2.} \\
\hline $1 \ldots$ & $35 \cdot 5^{8}$ & 60.34 & I. 34 & 2.74 & 97.8 \\
\hline $2 \ldots$ & 32.00 & $6 \mathrm{I} .39$ & 1.00 & 4.54 & 94.8 \\
\hline $3 \cdots 140$ & 30.00 & 62.72 & I. 78 & 5.50 & 98.0 \\
\hline $4 \cdots$ I 44 & $30.4 I$ & 62.88 & ง.77 & 4.94 & 96.0 \\
\hline
\end{tabular}

Bulb No. I of Series I, Table II, is the only experiment in which we have failed to detect nitrogen in appreciable amounts. It will be noticed that this bulb also lacks methane. The experiment was carried out in strict accord with the other members of the series, the medium being the same preparation, the inoculation from the same suspension culture. The reason for this variation is unexplained. 

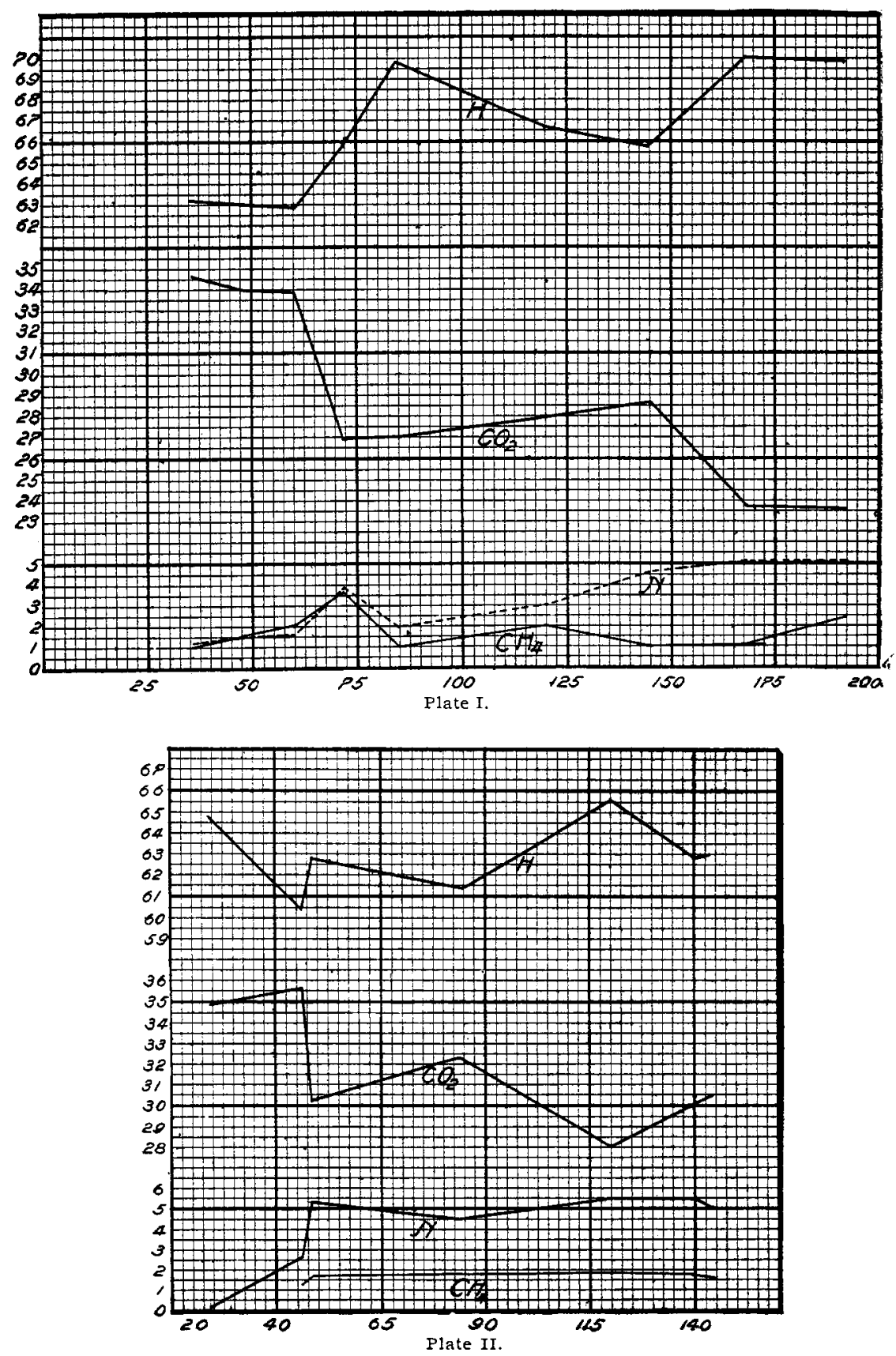


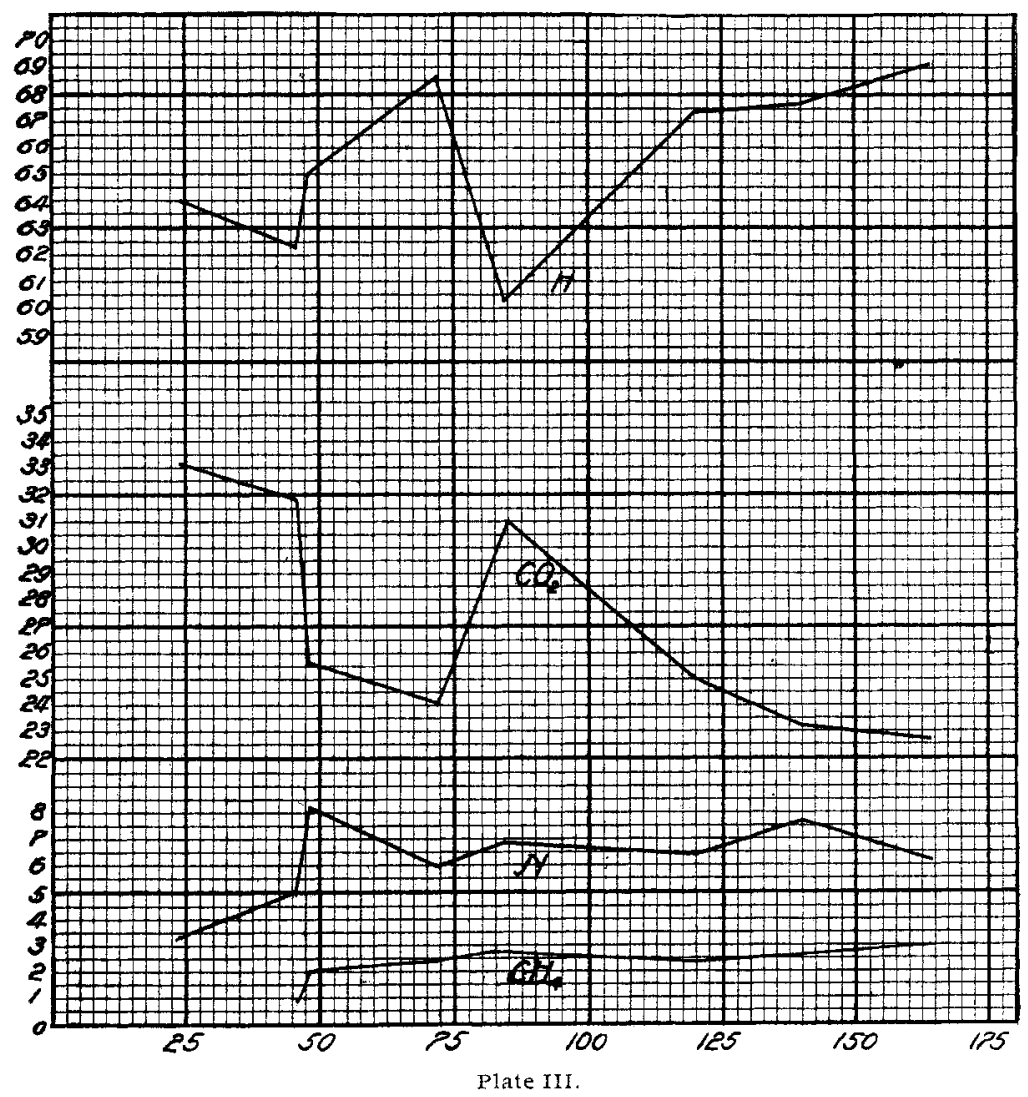

A comparison of the nitrogen obtained with and without the addition of extractives shows no appreciable nitrogen difference. If the amido nitrogen only is liberated we have in bulb 4 of Series 2 a quantity of nitrogen corresponding to $0.0184 \mathrm{gram}$ of creatine. According to Allen, ${ }^{1}$ Liebig's Extractum Carnis contains 29.32 per cent. meat bases. As 5 grams of the extract were added to I liter of the medium we have about 1.46 gram of extractives; or, as each bulb was supplied with $250 \mathrm{cc}$. of the fluid, 0.366 gram was available in each experiment. A very small quantity of amido nitrogen then is split off.

Because of the variability of peptones of different makes another sample, one obtained from Merck, was subjected to experiment.

1 "Commercial Organic Analysis," Vo1, IV, p. 31 . 
After careful drying it was made into a i per cent. solution containing salt and glucose as before. As in the similar experiments with Witte's peptone, extractives were omitted.

TABLE IV.

\begin{tabular}{|c|c|c|c|c|c|c|}
\hline No. $\quad \begin{array}{r}\mathrm{ex} \\
\end{array}$ & $\begin{array}{l}\text { Duration of } \\
\text { experiment. } \\
\text { Hours. }\end{array}$ & $\begin{array}{c}\text { Carbon } \\
\text { dioxide. } \\
\text { Per cent. }\end{array}$ & $\begin{array}{l}\text { Series } t \text {. } \\
\text { Hydrogen. } \\
\text { Per cent. }\end{array}$ & $\begin{array}{l}\text { Metbane. } \\
\text { Per cent. }\end{array}$ & $\begin{array}{l}\text { Nitrogen. } \\
\text { Per cent. }\end{array}$ & $\begin{array}{l}\text { Total } \\
\text { volume. } \\
\text { cc. }\end{array}$ \\
\hline$I \ldots$ & .. 24 & 33.41 & 64.07 & . & 2.52 & 52.0 \\
\hline $2 \ldots$ & .. 48 & 25.77 & 64.98 & 2.00 & 7.25 & 50.0 \\
\hline $3 \ldots \therefore$ & $\therefore 72$ & $24 \cdot 16$ & 68.60 & 2.18 & 5.06 & 57.0 \\
\hline $4 \cdots$ & . 120 & 24.89 & $\begin{array}{l}67.3^{6} \\
\text { Series } 2 .\end{array}$ & 2.35 & 5.40 & 53.0 \\
\hline$I \ldots$. & .. 46 & 31.80 & 62.33 & I.93 & 3.94 & 47.6 \\
\hline $2 \ldots$ & .. $8_{4}$ & 31.06 & 60.33 & 2.77 & 5.84 & 93.6 \\
\hline $3 \ldots$ & .. I 40 & 23.15 & 67.69 & 2.60 & 6.56 & 50.0 \\
\hline $4 \ldots$ & . I $16_{4}$ & 22.69 & 69.10 & 3.10 & 5.11 & 57.6 \\
\hline
\end{tabular}

With this sample of peptone there was a marked fall in the amount of gas produced, only about one-half the usual quantity being obtained. Bulb I, of Series I, Table IV, had made no methane at the end of twenty-four hours, but at the expiration of forty-eight hours, 2 per cent. was present in No. 2. The amount of carbon dioxide is distinctly less than that usually found.

VARIATION IN AMOUNT OF GASES PRODUCED.

A study of the results which have been obtained discloses an interesting relation from the standpoint of time variation. Table I, Series I, 2, and 3, were made under conditions as concordant as possible and should therefore be comparable. Uniting these three tables into one we get the following :

\begin{tabular}{|c|c|c|c|c|c|c|}
\hline $\begin{array}{ll} & D \\
\text { No. } & \end{array}$ & $\begin{array}{l}\text { Duration of } \\
\text { experimett. } \\
\text { Hours. }\end{array}$ & $\begin{array}{l}\text { Carbon } \\
\text { dioxide. } \\
\text { Per ceut. }\end{array}$ & $\begin{array}{l}\text { TABIE } \\
\text { Hydrogen. } \\
\text { Per cent. }\end{array}$ & $\begin{array}{l}\text { Methane. } \\
\text { Per cent. }\end{array}$ & $\begin{array}{l}\text { Nitrogen. } \\
\text { Per cent. }\end{array}$ & $\begin{array}{l}\text { Total } \\
\text { volume. } \\
\text { cc. }\end{array}$ \\
\hline I $\cdots$ & . $\quad 36$ & $34.5^{\circ}$ & 63.20 & 1.00 & I. 30 & 82.0 \\
\hline $2 \ldots$ & .. 48 & 34.00 & 63.00 & 1.5 & I. 50 & 93.0 \\
\hline $3 \cdots$ & 60 & 33.83 & 62.69 & I. 86 & I. 62 & 93.4 \\
\hline $4 \cdots$ & 72 & 26.6 & $65 \cdot 3$ & 4.30 & 3.80 & 98.0 \\
\hline $5 \cdots$ & 72 & $27 \cdot 5$ & 66.3 & 3.00 & 3.20 & 98.0 \\
\hline $6 \ldots$ & 72 & 26.45 & 65.82 & $3.6 \mathrm{I}$ & 4.12 & 64.0 \\
\hline $7 \cdots$ & .. 84 & 27.03 & 69.88 & 1.02 & 2.07 & 83.0 \\
\hline $8 \ldots$ & .. 120 & 28.00 & 66.5 & 2.00 & 3.05 & 90.0 \\
\hline $9 \cdots$ & .. I 44 & 28.48 & 75.83 & I.I 3 & $4.5^{6}$ & 80.0 \\
\hline Io... & .. 168 & 23.75 & 70.13 & 1.15 & $4 \cdot 97$ & 67.0 \\
\hline II ... & .. 192 & 23.59 & 69.88 & $2.3^{8}$ & 4.95 & 65.0 \\
\hline
\end{tabular}


There is here a marked difference in the quantitative relations of the various gases according, apparently, to the age of the culture. Charting these results, Plate I, we get a curve which at the end of thirty-six hours shows a maximum quantity of carbon dioxide. Seventy-two hours shows a decrease in carbon dioxide with a corresponding gain in hydrogen. During both of these periods the nitrogen and methane increase slowly but steadily, and are about equal in amount, the only exception being No. 5 , eighty-four hours, in which there is a marked absence of both these gases. The third period is marked by a second rise in the amount of carbon dioxide, which is, however, slight, the hydrogen remaining about stationary. The methane now falls behind but the nitrogen is increased, an increase which is maintained in the last period, though here the carbon dioxide is reduced to a minimum and the hydrogen rises to a maximum.

Uniting the series under Table III, and Table IV, we get Tables VI and VII (Plate II and III), where we find that the same principle holds good, though the length of time occupied by the different stages is not exactly the same in all cases.

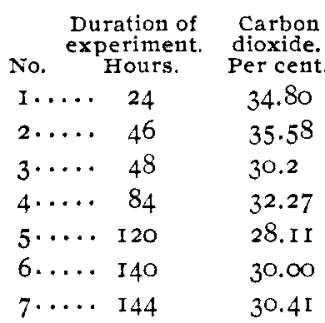

\begin{tabular}{|c|c|c|}
\hline No. $\quad \begin{array}{l}\mathrm{D} \\
\mathrm{ex}\end{array}$ & $\begin{array}{l}\text { Duration of } \\
\text { xperiment. } \\
\text { Hours. }\end{array}$ & $\begin{array}{l}\text { Carbon } \\
\text { dioxide. } \\
\text { Per cent. }\end{array}$ \\
\hline I $\ldots$ & . 24 & $33.4 \mathrm{I}$ \\
\hline $2 \ldots$ & 46 & 31.80 \\
\hline $3 \cdots$ & 48 & 25.77 \\
\hline $4 \cdots$ & $7^{2}$ & 24.16 \\
\hline $5 \cdots$ & .. 84 & 31.06 \\
\hline $6 \ldots$ & .. $\quad 120$ & 24.89 \\
\hline $7 \cdots$ & .. I 140 & 23.15 \\
\hline $8, \ldots$ & .. 164 & 22.69 \\
\hline
\end{tabular}

TABLE VI,

$\begin{array}{cccc}\begin{array}{c}\text { Hydrogen. } \\ \text { Per cent. }\end{array} & \begin{array}{c}\text { Methane. } \\ \text { Per cent. }\end{array} & \begin{array}{c}\text { Nitrogen. } \\ \text { Percent. }\end{array} & \begin{array}{c}\text { Total } \\ \text { volume. } \\ \text { cc. }\end{array} \\ 65.11 & \ldots . . & 0.09 & 100.0 \\ 60.34 & \text { I.34 } & 2.74 & 97.8 \\ 62.83 & 1.63 & 5.34 & 97.4 \\ 61.39 & 1.80 & 4.54 & 94.8 \\ 64.6 & 1.80 & 5.49 & 86.8 \\ 62.72 & 1.78 & 5.50 & 98.0 \\ 62.88 & 1.77 & 4.94 & 96.0\end{array}$

TABLE VII.

$\begin{array}{cccc}\begin{array}{c}\text { Hydrogen. } \\ \text { Percent. }\end{array} & \begin{array}{c}\text { Methane. } \\ \text { Percent. }\end{array} & \begin{array}{c}\text { Nitrogen. } \\ \text { Per cent. }\end{array} & \begin{array}{c}\text { Total } \\ \text { volume. } \\ \text { cc. }\end{array} \\ 64.07 & \ldots . . & \mathbf{2 . 5 2} & 52.2 \\ 62.33 & 1.93 & 3.94 & 47.6 \\ 64.98 & 2.00 & 7.25 & 50.00 \\ 68.60 & 2.18 & 5.06 & 57.00 \\ 60.33 & 2.77 & 5.84 & 39.6 \\ 67.36 & 2.35 & 5.40 & 53.00 \\ 67.69 & 2.60 & 6.56 & 50.00 \\ 69.10 & 3.10 & 5.11 & 57.6\end{array}$


There seems to be, on the whole, an intinate relation between the reducing power which liberates hydrogen and that which liberates nitrogen. Carbon dioxide is generated in greatest quantity at the outset, when, perhaps, the available oxygen is most plentiful and poisonous waste products are in smallest proportion. The reducing power gains strength in the latter stages, when the conditions for carbon dioxide production are not favorable. If, as some investigators maintain, the denitrifying ability of Bacillus coli communis is due to a secondary action rather than to a primary one, the rise in carbon dioxide after gas production has been maintained for some hours may be accounted for on the supposition that those substances produced by the organism which liberate nitrogen have, through the reaction involved in that liberation, been so altered that their toxicity for the bacteria is, in part at least, removed. The carbon dioxide function then asserts itself, producing again products which are hurtful. These, combined with those already present, resolutely check the liberation of carbon dioxide. The hydrogen-producing function, as well as the nitrogen, can still maintain its existence for a time, thereby raising the relative proportions of those gases.

We believe that the irregularity of the foregoing results, even when made with the greatest care that we could bestow, is worthy of consideration. For the very great majority of these variations we can offer no definite explanations. It seems to us that refinement in manipulation brings to view variations which can only be due to life conditions, to cope with which our methods are incalculably clumsy. Until these methods are improved the quantitative chemistry of the living cell cannot progress very far, and it is with the plea for further work along these lines that this communication is made. 